\title{
Factors Impacting Research Productivity of Academic Staff at the Iraqi Higher Education system
}

\author{
Alaa S Jameel ${ }^{\mathrm{a}}$, Abd Rahman Ahmad ${ }^{\mathrm{b}}$ \\ ${ }^{a, b}$ Faculty of Technology Management and Business, Universiti Tun Hussein Onn Malaysia, Malaysia. \\ ${ }^{a}$ College of Administrative and Financial Sciences, Department of Public Administration Cihan \\ University- Erbil, Iraq \\ Corresponding author: alaa.salam@cihanuniversity.edu.iq
}

To cite this article (APA): Jameel, A. S., \& Ahmad, A. R. (2020). Factors Impacting Research Productivity of Academic Staff at the Iraqi Higher Education system. International Business Education Journal, 13(1), 108126. https://doi.org/10.37134/ibej.vol13.1.9.2020

To link to this article: https://doi.org/10.37134/ibej.vol13.1.9.2020

\begin{abstract}
Research productivity is a vital element in enhancing the university ranking and, it is an important metric to measure the performance of academic staff. The purpose of this study is to identify the factors impacting research productivity of academic staff at Cihan University Erbil, Iraq. A survey was carried out among 87 academic staff randomly selected at the university to determine the impact of Fund, Collaboration, Information and Communication Technology (ICT), and Job Satisfaction on Research Productivity. The data was analyzed by using Smart PLS 3.2.9. The results indicated that Fund, Collaboration, ICT and Job Satisfaction had positive and significant impact on Research Productivity, although Fund has the highest impact on Research Productivity. The implication of this study is the management of universities should pay greater attention on research funding opportunities, rewarding collaboration among researchers, enabling ICT and improving job satisfaction to boost research productivity of the academic staff. For future research, it is recommended to measure the mediating roles of the variables and consider sampling academic staff from other universities to increase generalizability.
\end{abstract}

\section{Keywords:}

Research productivity, fund, collaboration, ICT, job satisfaction, academic staff, research publications.

\section{INTRODUCTION}

Research productivity is a crucial subject for researchers and students, as research results will impact the entire society positively. Similarly, research is vital to generate prosperity and develop nations. Research development in any country was measured through research productivity, such as publications in books and research articles. Nowadays, the primary source for the assessment of academic staff and academic institutions is publications. Additionally, the element showing the prestige of universities and countries is publication productivity.

Universities' and institutions' reliance on research funding to enhance academic staff productivity has raised. However, this strategy is becoming more structured and performance-oriented, with considerable delegations of responsibilities to the institution's leadership and researchers themselves in ensuring the consistency of research funding obtained. Most countries concentrate on public transparency for government funding for research activities and tend to use objective performance metrics for the allocation of funds (Butler, 2004). For that reason, the number of publications and grants awarded is related to 
increased funding applications and academic development, including staff promotion (Akl et al., 2012; Mahmood, Raewf, \& Hamadany, 2019). Another factor proposed by this study that influence research productivity is Information and Communication Technology (ICT), which refers to the adoption of technology by academic staff to help them access databases smoothly and communicate with other academic staff inside the country or with co-authors from different countries. According to Mousa, Jameel, and Ahmad (2019) the Ministry of Higher Education in Iraq aims to improve ICT utilization among academic staff in universities to increase their research productivity. Academic staff should be familiar with technological research tools for editting, citing articles, and data analysis such as Mendeley, EndNote, Turnitin, Smart PLS, and AMOS.

Limited and inadequate studies were conducted in developing countries (Shrum, 2005). The scientific production of the developing countries in international science repositories is not well represented, reflecting gaps in local needs priority and global thematic interests (Hassan, Mohamad, Haslinda, \& Mohd, 2020; Ynalvez \& Shrum, 2011). However, limited studies measured the academic staff productivity in the context of the Middle East countries, although Saudi Arabia received more attention compared to the other Middle East countries (Alghanim \& Alhamali, 2011; Alrahlah, 2016; Ghabban et al., 2019) including Iraq.

Education in Iraq is a widely contested subject. The legacy of the post-2003 period is witnessing the educational institutions as a target of religious, theological, and political tensions. Curricula and teaching approaches have been proven insufficient, obsolete, and controversial from primary schools education to universities (Jameel \& Ahmad, 2020) . Iraqi teaching failed to attract students and took away the element of fun learning. In general, memorizing facts offers less meaningful learning, training, and practical knowledge for students' development. Iraq spends less than any country on education in the world (Jameel \& Ahmad, 2019b). According to OECD statistics, Iraq, at best spends approximately 600USD per student. In 2016, Iraq allocated $\$ 5.7$ billion to education, but 91 per cent of the budget for education goes to salaries and very little investment in education (Al-Rubeai \& Al-Jaafari, 2019). The higher education system in Iraq is severely underfunded. The Ministry of Higher Education and Scientific Research estimated its immediate needs after the 2003 invasion at $\$ 1.2$ billion, but nothing like that has been made available (United States Institute of Peace, 2008).

However, the issue facing Iraqi universities and academic staff is the lack of research activities, which need to provide more publications and improve the current education system in Iraq. These issues placed the Iraqi universities in a low lank among regional universities (Jameel \& Ahmad, 2020; Raewf \& Thabit, 2015). The number of publications of Iraqi researchers in a reliable database is only 28,091 (SJR, 2020). This number of publications placed Iraq in $9^{\text {th }}$ position among 18 countries, and this rank is rather low if compared with other countries with a better position than Iraq, such as Lebanon and Jordan (SJR, 2020). Meanwhile, Iraq better than these countries in terms of resources, e.g., oil production and human resource in terms of population. The low universities rank as well as the number of publications were due to several reasons, such as low fund from government, security issues in previous years, lack of technology availability. However, language challenges may be another cause of flat publication rate even most Ph.D. holders have graduated from abroad universities (Jameel, Mahmood, \& Jwmaa, 2020; Thabit \& Raewf, 2015). Therefore, the purpose of this study is to examine the impact of Fund, Collaboration, ICT, and Job Satisfaction on academic staff Research Productivity in the Iraqi setting. 


\section{LITERATURE REVIEW}

\section{Research Productivity}

Research implies very careful, analytical, diligent analysis and review of phenomena, in particular, to try and find new knowledge and facts. While productivity refers to the output of academic staff such as publication, seminars, workshops, attending a conference. Research Productivity is the total number of works completed by academic staff in the university and related content over a while. The productivity of research is the interaction between the system input and output (Olakunle \& Olanrewaju, 2019). Research Productivity is calculated as the number of publications measured by the number of papers published by the academic staff in the last three years (Teodorescu, 2000). According to Alghanim and Alhamali (2011), Research Productivity is an essential predictor of the university and academic success. Measuring Research Productivity is the primary task of universities to enhance academic staff performance (Jameel \& Ahmad, 2020) and reflect the critical measures of a faculty's and academic staff productivity (Usang, Basil \&Lucy, 2007) as well as the measure of the individual's or group of authors' productivity (Liu \& Cheng, 2005; Thabit \& Raewf, 2018).

From the researchers' and students' perspectives, Research Productivity can have a beneficial impact on the local society (Jameel \& Ahmad, 2019a; Jameel \& Ahmad, 2020). The production of research comprises a broad variety of outputs: collections, technologies, databases, patents, books, and publications. Publications are a significant aspect of academic staff success as they perceived as a measure of personal merit (Alaaraj, 2018; Ynalvez \& Shrum, 2011). The number of publications is a vital indicator of the performance of academic staff (Al-Khalifa, 2014; Jameel \& Ahmad, 2020; Wilkinson \& Durden, 2015). The number of publications is the most critical consideration for performance assessment (Jameel \& Ahmad, 2019a; Toutkoushian, Porter, Danielson, \& Hollis, 2003; Alabass, Harjan, Teng \& Shah, 2019). The number of publication directly impact the universities ranking (Dhillon, Ibrahim, Selamat, \& Sani, 2013) and grade the countries (Yazit \& Zainab, 2007). Rankings are essential for various university missions, such as student instruction and research management (Pouris \& Pouris, 2010). Additionally, this ranking is used by developing countries as well as Iraq to build and enhance university education. Productivity in research is a highly weighted predictor in university rankings (Liu \& Cheng, 2005; Yazit \& Zainab, 2007).

The research productivity supports the creation of new collaborations to improved better management skills (Abramo, D’Angelo, \& Solazzi, 2011; Kato \& Ando, 2013). Scholars seeking to understand work efficiency have concentrated on a variety of variables, such as individual scholars' profiles, the learning climate, scientific career structure, the science compensation system, and, most recently, models of cooperation (Defazio, Lockett, \& Wright, 2009). Several previous studies measured the Research Productivity in several indicators such as journal articles, books, conference papers (Teodorescu, 2000), technical reports, and patents (Olakunle \& Olanrewaju, 2019). Several factors have confirmed the impact of Fund (Nafukho et al., 2019; Iqbal and Mahmood, 2011; Alabass, Harjan, Teng \& Shah, 2019), Collaboration (Abramo et al., 2011; Kato and Ando 2013), ICT (Ghabban et al., 2019) and Job Satisfaction (Jameel \& Ahmad, 2020) those factors the most vital to increase the productivity of research among academic staff. 


\section{Fund}

A substantial portion of the entire research operation is supported by publicly funded scientific work, which also has a beneficial impact on industrial research and development. One of the most important and useful sources of economic capital is research funding (Feng, 2020). The provision of funds is a critical factor for the institutions to motivate academic staff; for instance, the availability of funds for the establishment of research laboratories would boost academic satisfaction and increase the number of publications. Researchers agree that universities should promote and inspire more researchers by providing enough funding for projects of this nature (Ahmad, Soon, \& Yee, 2016; Alrahlah, 2016; Rahman Ahmad, Farley, \& Kim Soon, 2014). The institutional policies needs to concentrate on enhancing the funding structure and increasing the postdoctoral role. Working in such setting includes integrity and academic excellence, which in effect inspire an aura of intellectual rivalry to improve awareness and dissemination of research outputs (Shahbazi-Moghadam, Salehi, Ale Ebrahim, Mohammadjafari, \& Gholizadeh, 2015). The allocation of research grants following the work output assessment is usually measured (Butler, 2004).

In addition to the vital role of research funds in improving university publication rates, grant approval authorities are of paramount importance (Ahmad \& Farley, 2014; Rahman Ahmad, Farley, \& Naidoo, 2013; Shahbazi-Moghadam et al., 2015). When it comes to some of the social science disciplines, the issue emerges from the fact that the field is facing more limited prospects for ISI-indexed journals, thus a lower chance of funding research (Shahbazi-Moghadam et al., 2015). The results of that decrease the number of publications and grant additionally lead to negative perceptions among the researchers as well as the colleges (Shahbazi-Moghadam et al., 2015; Zhang, Abdulreza, Harjan \& Shah, 2019). Meanwhile, when funds were distributed, there is no effort to distinguish between reliable and quality journals and others (Butler, 2004). Additionally, project funding should not be underlined in promotional evaluations of faculty performance appraisal (Ahmad, Farley, \& Kim-soon, 2013; Ahmad, Farley, \& Kim Soon, 2014; Garcia \& Sanz-Menéndez, 2005). According to Butler (2004) Spanish authors have reacted to funding opportunities by growing their research output with ISI indexed journals publications and increasing Spanish science productivity and internationalization, where the goals have been accomplished in Spain through funding. In support, review papers and funded grants were also considered as a measure of academics success (Baumann et al., 2019).

According to Nafukho, Wekullo and Muyia (2019) Fund positively associated with research productivity. A study further reported that Fund had the highest mean score among the faculty staff to conduct researches (Iqbal \& Mahmood, 2011). They emphasized that the universities should provide enough funding to academic staff to conduct and increase research activities (Iqbal \& Mahmood, 2011).

Other several studies have noted that funds positively correlated with research productivity (Barnett, Graves, \& Blakely, 2015; Hottenrott \& Lawson, 2017; Nafukho et al., 2019). Moreover, some researchers indicated that there is a relationship between the grant amount and publication productivity (Defazio et al., 2009; Feng, 2020; Milesi, Brown, Hawkley, Dropkin, \& Schneider, 2014).

\section{$H_{1}:$ Fund has a positive and significant impact on Research productivity among academic staff.}




\section{Collaboration}

Collaboration is a mechanism of interaction between information producers that require efficient communication and information exchange, sharing expertise, skills, and resources, and working together, producing, and reporting the results. Otherwise, collaboration is a close association of two or more researchers with one or more common objectives in a research project-including the fundamental aim of resources acquisition.

According to Ynalvez and Shrum (2011) collaboration stems from the arrangement of social ties between producers of information. Practical research projects transform into new tools that promote social initiatives, such as creating awareness by presenting at conferences and journals, or achieving specific goals. The number of publications increased through collaborations (Ductor, 2015). Collaboration among academic staff leads to several advantages, e.g., collaboration can facilitate the most effective use of time, as it enables the distribution of work between the various team participants (Barnett, Ault, \& Kaserman, 1988). The distribution of work also allows team members to work on multiple aspects of a project in parallel, minimizing the time required to complete the project (Beaver, 2001). Besides, it may reduce the chance of rejection by the journal editors (Barnett et al., 1988; Beaver, 2001). Newman (2011) indicated that several researchers might have a potent knowledge of each other, but it is not necessarily they collaborate or co-author an article. However, sometimes a researcher does not establish collaborations to increase research productivity, but rather to strengthen the relational and political aspects of his social capital (Alaarj, Mohamed, \& Bustamam, 2016a, 2016b; Pezzoni, Sterzi, \& Lissoni, 2012; Ynalvez \& Shrum, 2011).

There is an argument regarding the impact of collaboration on research productivity. Abramo et al. (2011) and Kato and Ando (2013) indicated a positive effect of collaboration on Research Productivity and research performance (Ductor, 2015; Abozaid, et al,2019). In contrast, a study by Ynalvez and Shrum (2011) among the Philippines scientists, found that the scientific collaboration does not impact publication productivity among them. (He, Geng and Campbell-Hunt (2009) indicated the Research Productivity affected only by an international collaboration but none with domestic collaboration. Conversely, Abramo, D'Angelo and Murgia (2017) found collaboration among researchers in the level of domestic positively impacted Research Productivity.

\section{$\mathrm{H}_{2}$ : Collaboration has a positive and significant impact on Research Productivity among academic staff.}

\section{Information and Communications Technology}

Technological development offers significant opportunities to improve both the quantity and innovative quality of academic research productivity. Academic staff with a higher technical tendency would have an advantage in the development of research productivity due to the efficiency of these technologies. The productivity improvement ability of these new technologies, especially in areas such as medical science, has been well documented (Callaghan, 2015).

According to Mousa et. al (2019), ICT is a critical factor in enhancing university employees' productivity. The internet connection provided by the university would allow the academic staff to share their expertise with colleagues in the same university, in the same 
country or abroad (Ghabban et al., 2019). In terms of the possible benefits of applying technology to the research process itself, more business academics may also be more inclined to pursue new technical possibilities in their study (Rubin \& Callaghan, 2019). However, several studies have shown the value of academics' ability to use computers to improve research productivity, such as using analysis applications, for example, AMOS, SPSS, and others (Africa, 2015; Jameel, 2018). According to Khademi, Ismail, Lee and Shafaghat (2015), the accessibility of external resources and funding has a direct effect on an institution's research productivity. Several barriers such as computer shortages, lack of technological support, and insufficient infrastructure faced by the university's academic staff may reduce their Research Productivity (Alghanim \& Alhamali, 2011), and IT availability (Jameel \& Ahmad, 2018;Jameel, Karem, \& Mahmod, 2017).

Empirically, the study performed among academic staff in the Iraqi context indicated that the ICT was able to enhance academic staff performance (Mousa et al., 2019). Knowledge sharing among academic staff at Iraqi universities was impacted by ICT adoption and improved their knowledge sharing (Mousa et al., 2019). Likewise, ICT has a positive impact on Research Productivity in Saudi Universities (Ghabban et al., 2019). However, technology has also been found to have insignificant relation with Research Productivity (Rubin \& Callaghan, 2019).

\section{H3: ICT has a positive and significant impact on Research Productivity among academic staff.}

\section{Job Satisfaction}

Job Satisfaction is an indicator of well-being than pleasure since it only includes well-being linked to employment. According to Locke (1970, p. 484), "the happy worker is the productive worker." Furthermore, Job Satisfaction is a crucial factor that can be taken into consideration to motivate university staff to boost their productivity (Jameel \& Ahmad, 2019b; Jameel \& Ahmad, 2020; Khan \& Ghouri, 2018). According to Jameel and Ahmad (2019a) universities should have a positive and safe Job Satisfaction climate. Job Satisfaction is believed to be closely tied to workers' mental wellbeing, and the organizations' dedication to high productivity and a healthy workplace and Job Satisfaction can contribute to stress reduction through work incentives (Ahmad \& Jameel, 2018; Fuzi \& Fuzi, 2019; Karem, Mahmood, Jameel, \& Ahmad, 2019). Courses taught, interactions with peers, job security, and the way the university managed its staff will measure academic staff satisfaction and academic staff performance increased by Job Satisfaction among academic staff at universities (Ghabban et al., 2019; Ghran, Jameel, \& Ahmad, 2019). On regards to satisfaction and productivity ratio, earlier study have developed a model to analyses the activation based on the premise that there is a relationship between satisfaction and productivity (Porter \& Lawler, 1968). The model was based on the assumption that incentives produce satisfaction and often performance leads to the remuneration of various kinds that increase employee satisfaction. Research culture and salary are essential elements in improving Job Satisfaction among academic staff and enhance their productivity (Alaaraj, Mohamed, \& Ahmad Bustamam, 2018; Alaarj, Mohamed, \& Bustamam, 2017; Ghabban et al., 2019). The factors that impact Job Satisfaction among academic staff at universities and increased their productivity and performance are job security, financial reward, empowerment (Ahmad \& Jameel, 2018), technological support and working environment (Shin \& Jung, 2014). 
According to Locke (1976) there is a reciprocal between satisfaction and productivity and therefore, satisfaction does not lead to productivity, but productivity leads to satisfaction. Satisfaction primarily has an indirect impact on productivity, generating a sense of responsibility to the company and its goals. Outside this productivity ratio: satisfaction: productivity, the consequent increase in satisfaction is possible, provided that productivity increases other work-related payments (promotion, authority, bonuses, etc.), which contribute to increased satisfaction (Personal \& Archive, 2008).

The study by Mcneece (1981) is considered as one of the earliest studies which examined the relationship between job satisfaction and publication, reflecting one of the academic staff productivity. More recent study by Jameel and Ahmad (2020) conducted among academic staff in Iraqi public universities examined the impact of Job Satisfaction on Job Performance and productivity. The study revealed that satisfaction profoundly impacted academic staff productivity (Jameel and Ahmad, 2020). In Middle East countries in Saudi Arabia, Ghabban et al., (2019) found positive impact of Job Satisfaction on Research performance among Saudi academic staff.

\section{$H_{4}$ : Job satisfaction has a positive and significant impact on Research productivity among academic staff.}

\section{METHODOLOGY}

The study was conducted among the academic staff at Cihan University Erbil, Iraq. The data was collected by using self-administered questionnaires which were distributed randomly among the academic staff. Altogether, 100 questionnaires were distributed, and only 92 were returned. After data screening for missing value and incomplete data, the total number of questionnaires valid to be analyzed were 87 . The data were then analyzed by using Smart PLS 3.2.9.

The demographic results showed that $64 \%$ of the respondents are male and $36 \%$ are female. In conjunction with age distribution, only $8 \%$ were less than 29 years old, while the majority of respondents (39\%) are 30 to 40 years old, $24 \%$ are 41 to 50 years old and lastly $20 \%$ are 51 to 65 years old. The academic title shown as expected where most of the respondents are assistant lecturer (43\%), while the lecturer, assistant professor and professor are $32 \%, 24 \%$ and $1 \%$ respectively. Regarding the level of education, $43 \%$ hold Master degree and $57 \%$ hold Ph.D degree.

The questionnaire consists of two sections; demographic questions, and variables questions where all the items were adapted from prior studies. Research Productivity consisted of 5 items (Ibegbulam \& Jacintha, 2016) (Ghabban et al., 2019), the Collaboration comprised of 5 items (Alzuman, 2015), Fund consisted of 5 items (Alrahlah, 2016; Alzuman, 2015), ICT contained 4 items (Ghabban et al., 2019) and Job Satisfaction had 6 items (Personal \& Archive, 2008; Jameel \& Ahmad, 2020). The questionnaire applied five-point Likert scale ranging fron (1) Strongly disagree to (5) Strongly agree for all the close-ended questions. 


\section{RESULTS}

The study employed smart PLS software to analyse the data, and according to Hair, Sarstedt, Hopkins and Kuppelwieser (2014), there are two primary steps in PLS measurement and structural model.

\section{Model measurement (outer model)}

In this step, the reliability, convergent validity, and discrimination validity were examined. The composite reliability (CR) should exceed the 0.70 , and the average variance extracted (AVE) should be $>0.50$ while the factor loading (outer loading) $>0.7$ (Chin, 2010) and (Hair et al., 2014). Table 1 illustrates all the results regarding CR items exceeded the minimum requirement 0.7 all items above 0.9 , which reflect high internal consistency.

Additionally, the purpose of AVE is to test the convergent validity as well as divergent validity, AVE in case of the reflective model represents the average of commonality for each latent factor (Hair et al., 2016). All items showed acceptable AVE values >0.50, the lowest AVE is Collaboration with 0.72, and the highest AVE is ICT with 0.888. Lastly, measurement loadings are the standardized path weights connecting the factors to the indicator variables. Loadings should be significant. In general, the larger the loadings, the stronger and more reliable the measurement model. Indicator reliability may be interpreted as the square of the measurement loading (Hair et al., 2016). The loading of all items is above 0.70 , which is acceptable. However, Cronbach's alpha was additionally checked to ensure reliability as a recommended criteria and all above 0.7 (see Table 1).

Table 1: Validity and reliability

\begin{tabular}{|c|c|c|c|c|c|}
\hline Constructs & Items & $\begin{array}{c}\text { Outer } \\
\text { loading }\end{array}$ & $\begin{array}{c}\text { Cronbach's } \\
\text { Alpha }\end{array}$ & $\begin{array}{c}\text { CR } \\
>0.7\end{array}$ & $\begin{array}{l}\text { AVE } \\
>0.5\end{array}$ \\
\hline \multirow{5}{*}{$\begin{array}{l}\text { Research } \\
\text { Productivity }\end{array}$} & RP1 & 0.737 & \multirow{4}{*}{0.897} & \multirow{5}{*}{0.925} & \multirow{5}{*}{0.714} \\
\hline & RP2 & 0.899 & & & \\
\hline & RP3 & 0.899 & & & \\
\hline & RP4 & 0.903 & & & \\
\hline & RP5 & 0.770 & \multirow{7}{*}{0.899} & & \\
\hline \multirow{5}{*}{ Fund } & FD1 & 0.793 & & \multirow{6}{*}{0.926} & \multirow{6}{*}{0.715} \\
\hline & FD2 & 0.882 & & & \\
\hline & FD3 & 0.911 & & & \\
\hline & FD4 & 0.841 & & & \\
\hline & FD5 & 0.794 & & & \\
\hline \multirow{5}{*}{ Collaboration } & $\mathrm{CO} 1$ & 0.836 & & & \\
\hline & $\mathrm{CO} 2$ & 0.897 & \multirow{4}{*}{0.894} & \multirow{4}{*}{0.921} & \multirow{5}{*}{0.702} \\
\hline & $\mathrm{CO} 3$ & 0.886 & & & \\
\hline & $\mathrm{CO} 4$ & 0.749 & & & \\
\hline & $\mathrm{CO} 5$ & 0.811 & & & \\
\hline \multirow{4}{*}{ ICT } & ICT1 & 0.966 & \multirow{4}{*}{0.957} & \multirow{4}{*}{0.969} & \\
\hline & ICT2 & 0.970 & & & \multirow{3}{*}{0.888} \\
\hline & ICT3 & 0.962 & & & \\
\hline & ICT4 & 0.867 & & & \\
\hline \multirow{6}{*}{$\begin{array}{l}\text { Job } \\
\text { satisfaction }\end{array}$} & JS1 & 0.861 & \multirow{6}{*}{0.931} & \multirow{6}{*}{0.945} & \multirow{6}{*}{0.741} \\
\hline & JS2 & 0.926 & & & \\
\hline & JS3 & 0.826 & & & \\
\hline & JS4 & 0.862 & & & \\
\hline & JS5 & 0.835 & & & \\
\hline & JS6 & 0.851 & & & \\
\hline
\end{tabular}


Note: ICT: Information and Communications Technology, CR: composite reliability, AVE: average variance extracted

\section{Discrimination validity}

This study examined the discriminant in two ways; Fornell and Lacker (1981) criterion and heterotrait-monotrait ratio. First, according to the Fornell and Larcker, (1981) criterion, the latent factor must have more variance than other latent. Our result met this criterion (see Table 2).

Table 2: Fornell-Larcker criterion for discriminant validity

\begin{tabular}{cccccc}
\hline & CO & RP & FD & ICT & JS \\
\hline CO & $\mathbf{0 . 8 3 8}$ & & & & \\
RP & 0.537 & $\mathbf{0 . 8 4 5}$ & & & \\
FD & 0.54 & 0.536 & $\mathbf{0 . 8 4 5}$ & & \\
ICT & 0.481 & 0.475 & 0.311 & $\mathbf{0 . 9 4 2}$ & \\
JS & 0.12 & 0.301 & 0.18 & 0.184 & $\mathbf{0 . 8 6 1}$ \\
\hline
\end{tabular}

Note: CO: Collaboration, RP: Research Productivity, FD: Fund, ICT: Information and Communication Technology, JS: Job Satisfaction

The second way of discriminant assessment is heterotrait-monotrait (HTMT) ratio. In a well-fitting model, heterotrait correlations should be smaller than monotrait correlations, meaning that the HTMT ratio should be below 0.9 (Hair et al., 2016). our results showed all variables obtained less than the maximum value, meaning that the discriminant validity has been established between a given pair of reflective constructs.

Table 3: HTMT discriminant validity

\begin{tabular}{|c|c|c|c|c|c|}
\hline & $\mathrm{CO}$ & RP & FD & ICT & JS \\
\hline \multicolumn{6}{|l|}{$\mathrm{CO}$} \\
\hline $\mathrm{RP}$ & 0.589 & & & & \\
\hline FD & 0.606 & 0.588 & & & \\
\hline ICT & 0.508 & 0.519 & 0.334 & & \\
\hline JS & 0.161 & 0.300 & 0.184 & 0.175 & \\
\hline
\end{tabular}

Note: CO; Collaboration, RP; Research Productivity, FD; Fund, ICT; Information and Communication Technology, JS; Job satisfaction

\section{Structural Model (Inner Model)}

After ensuring that there was no issues with the validity, reliability, and discriminant, the next step is to measure the hypotheses by Structural Model (Inner Model).

The first step is to determine the $\mathrm{R}^{2}$ and $\mathrm{Q}^{2}$. $\mathrm{R}^{2}$ represents how much the independent variables explain the dependent variable. The result of $\mathrm{R}^{2}$ is 0.455 meaning that the independent variables could explained the dependent variable by 45 percent. According to Chin (2010), this value is at a moderate level.

The purpose of $\mathrm{Q}^{2}$ is an estimate of the predictive ability or predictive relevance of the model. $\mathrm{Q}^{2}$ result obtained was 0.306 which was above zero, and positive, meaning that it is acceptable according to Henseler, Ringle and Sinkovics (2009). It indicates that the model has predictive relevance of its factors (Fund, Collaboration, ICT and Job Satisfaction) on Research Productivity. 
To test the hypotheses by PLS, we run the bootstrapping with 5000 subsamples as recommended and the purpose behind the large subsamples is to ensure the stability of results (Hair et al., 2016). Table 4 illustrates the structural model results hypotheses should accept in the level of T- statistics (T-value) $>1.96$ due to the error $5 \%$ and confidence $95 \%$ and P-value should be $<0.05$.

The impact of Fund on Research Productivity shown the path coefficient is 0.302 where the coefficient close to 1 represents a strong relationship whereas the coefficient close to 0 indicates weak relationship (Hair et al., 2016). T-Value shown $2.239>1.96$ while the PValue is significant and less than 0.05 ( $\mathrm{P}$-Value $=0.025$ ), thus, $H_{l}$ is accepted. This result is in line with the previous findings by Hottenrott and Lawson, (2017) and Nafukho et al (2019).

The second hypothesis examined the impact of Collaboration on Research Productivity among academic staff, and the result indicated there was a positive and significant impact of Collaboration on Research Productivity. The path coefficient is 0.214, which is approaching the weak relationship (Hair et al., 2016). Since T-Value $2.140>1.96$ and the P-Value $0.032<0.05$; thus, $H_{2}$ is accepted. Similar result was confirmed by Ductor (2015).

The path coefficient of the impact of ICT on Research Productivity is 0.233 while the T- Value and P-value, 2.018 and 0.044 respectively, met the requirements criteria. Thus, the third hypothesis is also accepted. The result bolstered the studies of Ghabban et al., (2019), Jameel and Ahmad (2020), and Mousa et al. (2019). On the other hands, the last hypothesis confirmed the impact of Job Satisfaction on Research Productivity among academic staff with the path coefficient 0.175 and T-Value $2.181>1.96$ and P-Value $0.029<0.05$. Thus, $H_{4}$ is accepted. The result is supported by the previous finding (Ghabban et al., 2019). Figure 1 depicts the result of the path coefficient and t-value.

Table 4: Result of hypotheses

\begin{tabular}{lcccc}
\hline \multicolumn{1}{c}{ Hypotheses } & $\boldsymbol{\beta}$ & T Values & P Values & Remarks \\
\hline H1 Fund -> Research Productivity & 0.302 & 2.239 & 0.025 & Accepted \\
H2 Collaboration -> Research Productivity & 0.241 & 2.140 & 0.032 & Accepted \\
H3 ICT -> Research Productivity & 0.233 & 2.018 & 0.044 & Accepted \\
H4 Job Satisfaction -> Research Productivity & 0.175 & 2.181 & 0.029 & Accepted \\
\hline
\end{tabular}




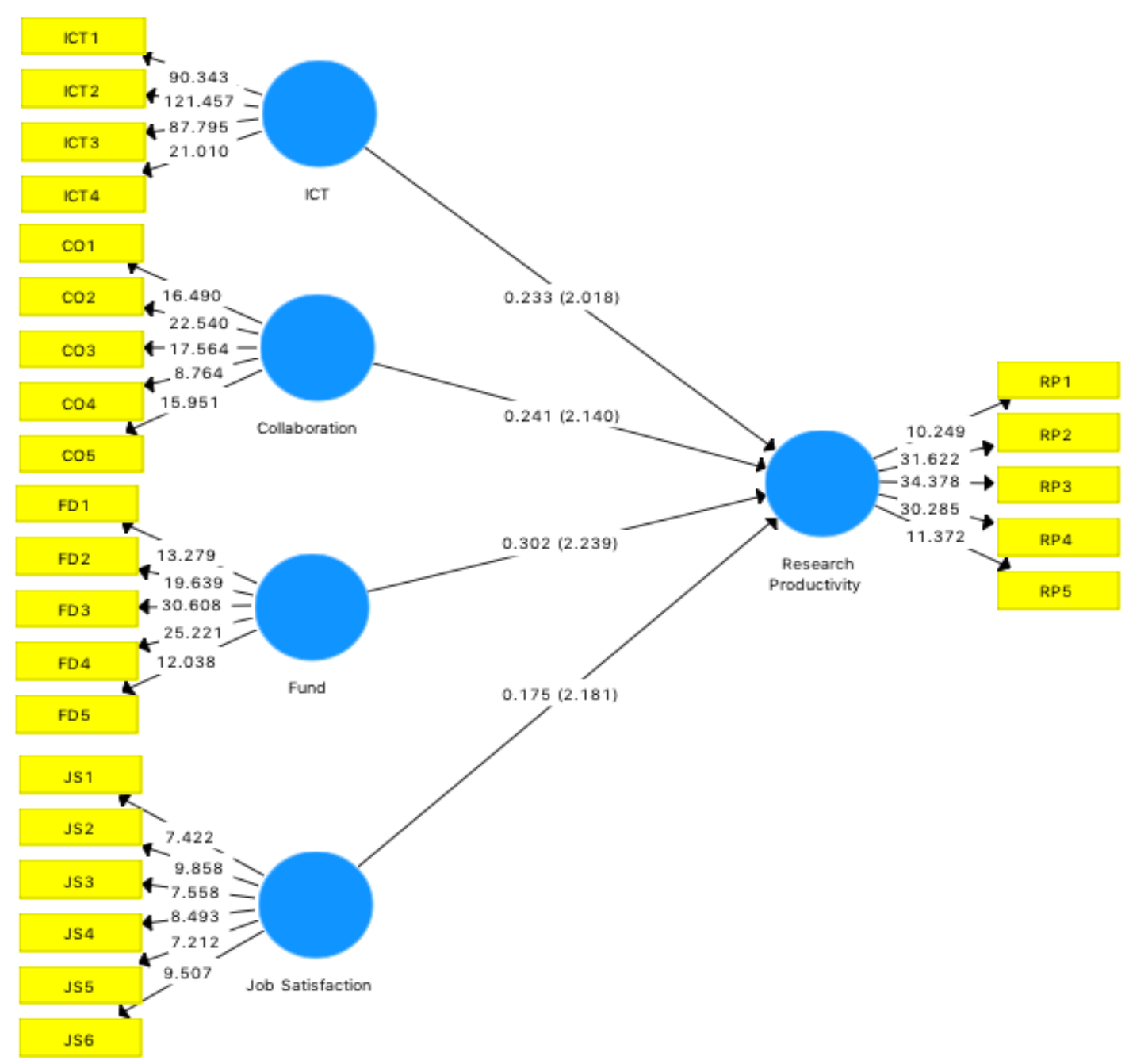

Figure 1: Research model and t-value

\section{DISCUSSION}

The purpose of this study is to identify the factors impacting research productivity of academic staff at Cihan University Erbil, Iraq. All the hypotheses were accepted while Fund indicated a critical factor that impacts on Research Productivity among academic staff than other factors (Collaboration, ICT and Job Satisfaction). Increasing the investment for research facilities, research funding and the salaries of researchers are critical strategies to boost academic productivity at universities. Improvement on research funding processes and a growing awareness of the value of academic editing and translation facilities are also positively linked to academic productivity. However, university management could introduce projects that attract research funding intending to increase funding rates. Increasing and receiving research funding by academic staff represent an excellent advantage to attend academic conferences especially abroad and publish papers with high-rank journals because the researchers in Iraq and Middle East countries typically require proofreading services for their articles due English language barrier.

Research Productivity was positively predicted by Collaboration. The collaboration leads to enhancing the academic staff productivity at the international or domestic level and 
positively impact the number of publication as well as the conference participation. Moreover, collaboration and interactions with colleagues, for instance, conference contact and international cooperation, provide the intellectual sharing necessary for the production of expertise and the creation of new ideas.

ICT positively impacted Research Productivity among academic staff. New ICT has become the means of long-distance cooperation by being a crucial tool in sharing the information and knowledge among academics, which will positively increase their productivity. However, with the development of science and strong aspirations of new ICT of promoting more excellent collaborations between scientists in developed and emerging fields, this presumption is usually applied to research institutions in developing countries to enhance the academic productivity. Additionally, the advantages of ICT in resource-constrained research systems need to be explored thoroughly and diversified.

ICT is important to academic staff to increase their productivity because usually the researchers need to use the technology when communicating with other researchers abroad, and mainly the result of this study indicated the collaborations internationally and nationally are able to enhance the productivity among academic staff. However, researchers need to use different technology tools including AMOS, SPSS, Smart PLS, and other analysis software. Meanwhile, ICT and technological tools play a crucial role in enhancing the researchers' productivity and help the researchers to access academic database.

Job Satisfaction has positive impact on Research Productivity among the academic staff. Universities need to pay more attention to their academic staff's job satisfaction in terms of empowerment, justice, workload, and training to enhance staff skills particularly in writing articles and how to use the software in research, e.g., management references EndNote, Mendeley, and Turnitin. Higher education depends on qualified resources to attain high-level educational goals, such as scholarly publications. For the quality of higher education, academic staff job satisfaction and encouragement are essential to achieve the universities and higher education institutions in Iraq goals, which are the primary purpose is to enhance Iraqi universities' ranking. Additionally, in higher education institutions, academic staff are a major factor, and job satisfaction leads to improved teaching and research productivity.

\section{CONCLUSION, LIMITATIONS, AND IMPLICATIONS}

Research Productivity plays an essential role in enhancing and increasing the university ranking, which align with the primary purpose of the Ministry of Higher Education in Iraq, to place the Iraqi universities in the right place among Middle East countries. Fund, Collaboration, ICT, and Job Satisfaction reported in this study highly contributing to an increased number of publications. However, our result indicated the Fund as the most important factor for encouraging academic staff to enhance their publications. The Collaboration in general, whether nationally or internationally, increases research productivity, and universities should enhance this factor and create the culture at university for that. To enhance scholarly communications, to increase work quality, to improve work volumes, to share information, to reduce duplication of jobs, and to accelerate publishing, the use of ICT is necessary.

The study has some limitations, like any other study. First, the research was conducted in one university with small sample size. Second, the study focused only on four 
factors in general and examined the direct effect only. Future research could be conducted with a larger sample size with more than one university to be able to generalize the results and increase the possibility of determining the causal effect of these factors by examining the mediating roles.

The implications of this study have clarified some elements which could led to enhanced research productivity through perceptions of a sample of academic staff at Cihan University Erbil. However, other Iraqi universities can consider these factors to improve research productivity.

\section{REFERENCES}

Abramo, G., D’Angelo, A. C., \& Murgia, G. (2017). The relationship among research productivity, research collaboration, and their determinants. Journal of Informetrics, 11(4), 1016-1030. https://doi.org/10.1016/j.joi.2017.09.007

Abramo, G., D’Angelo, C. A., \& Solazzi, M. (2011). The relationship between scientists' research performance and the degree of internationalization of their research. Scientometrics, 86(3), 629-643. https://doi.org/10.1007/s11192-010-0284-7

Africa, S. (2015). A Model Using ICT Adoption and Training to Improve the Research Productivity of Academics. Ph.D. Thesis, Durban University of Technology, Durban, Africa,.

Ahmad, A. R., \& Farley, A. (2014). Funding Reforms in Malaysian Public Universities from the Perspective of Strategic Planning. Procedia - Social and Behavioral Sciences, 129, 105-110. https://doi.org/10.1016/j.sbspro.2014.03.654

Ahmad, A. R., Farley, A., \& Kim-soon, N. (2013). Funding Reforms in Malaysian Public Universities: Transitions towards Competitive Funding. Australian Journal of Basic and Applied Sciences, 7(10), 553-561.

Ahmad, A. R., Farley, A., \& Kim Soon, N. (2014). Categorisation of public universities funding. Asian Social Science, 10(10), 57-67. https://doi.org/10.5539/ass.v10n10p57

Ahmad, A. R., Soon, N. K., \& Yee, K. S. (2016). Performance based funding mechanisms: The applicability study in the context of Malaysian public universities. International Business Management, Vol. 10, pp. 3872-3877.

Ahmad, A. R., Farley, A., \& Kim Soon, N. (2014). Impact of the government funding reforms on the research and development at Malaysian public universities. Asian Social Science, 10(14), 13-22. https://doi.org/10.5539/ass.v10n14p13

Ahmad, A. R.., Farley, A., \& Naidoo, M. (2013). Asian Economic and Financial Review 2(4):562-576 562 Funding Crisis In Higher Education Institutions: Rationale For Change. Asian Economic and Financial Review, 2(4), 562-576. Retrieved from http://www.aessweb.com/pdf-files/562-576.pdf

Ahmad, M. A.-A., \& Jameel, A. S. (2018). Factors Affecting on Job Satisfaction among Academic Staff. Polytechnic Journal, 8(2), 119-128. https://doi.org/https://doi.org/10.25156/ptj.2018.8.2.161 
Akl, E. A., Meerpohl, J. J., Raad, D., Piaggio, G., Mattioni, M., Paggi, M. G., ... Schünemann, H. J. (2012). Effects of assessing the productivity of faculty in academic medical centres: A systematic review. Cmaj, 184(11), 602-612. https://doi.org/10.1503/cmaj.111123

Al-Khalifa, H. S. (2014). Scientometric assessment of Saudi publication productivity in computer science in the period of 1978-2012. International Journal of Web Information Systems, 10(2), 194-208. https://doi.org/10.1108/IJWIS-01-2014-0001

Alabass, H. S. H. H., Harjan, S. A., Teng, M., \& Shah, S. S. H. (2019). The Impact of Corporate Political Connections on Corporate Financial Decisions: Evidence from an Emerging Market. Journal of Management Information and Decision Sciences.

Al, H. M. K., Zhang, J., Abdulreza, M. S., Harjan, S. A., \& Shah, S. S. H. (2019). The Role of Financial Inclusion and Competitive Advantage: Evidence from Iraqi Islamic Banks. International Journal of Economics and Financial Issues, 9(3), 193.

Alaaraj, S. (2018). Knowledge Management Capability, Trust, and Performance of Manufacturing Companies in Emerging Economies. International Journal of Management and Applied Science, 4(8), 45-53.

Alaaraj, S., Mohamed, Z. A., \& Ahmad Bustamam, U. S. (2018). External growth strategies and organizational performance in emerging markets: The mediating role of interorganizational trust. Review of International Business and Strategy, 28(2), 206-222. https://doi.org/10.1108/RIBS-09-2017-0079

Alaarj, S., Mohamed, Z. A., \& Bustamam, U. S. A. (2016a). The Mediating Role of InterOrganizational Trust between External Growth Strategies and Organizational Performance of Malaysian Companies. Advance in Global Business Research, 13(1).

Alaarj, S., Mohamed, Z. A., \& Bustamam, U. S. A. (2017). The effect knowledge management capabilities on performance of companies: A study of service sector. International Journal of Economic Research, 14(15), 457-470.

Alaarj, S., Mohamed, Z. A., \& Bustamam, U. S. B. A. (2016b). Mediating Role of Trust on the Effects of Knowledge Management Capabilities on Organizational Performance. Procedia - Social and Behavioral Sciences, 235(2016), 729-738. https://doi.org/10.1016/j.sbspro.2016.11.074

Alghanim, S. A., \& Alhamali, R. M. (2011). Research productivity among faculty members at medical and health schools in Saudi Arabia: Prevalence, obstacles, and associated factors. Saudi Medical Journal, 32(12), 1297-1303.

Alrahlah, A. A. (2016). The impact of motivational factors on research productivity of dental faculty members: A qualitative study. Journal of Taibah University Medical Sciences, 11(5), 448-455. https://doi.org/10.1016/j.jtumed.2016.06.006

Al-Rubeai, Mohamed. Al-Jaafari, Ahmed K.(2019). What problems face Iraqi education?.Middle east one. https://middle-east-online.com/en/what-problems-faceiraqi-education

Alzuman, A. (2015). Scholars Compass Faculty Research Productivity in Saudi Arabian Public Universities: A Human Capital Investment Perspective. Retrieved from 
http://scholarscompass.vcu.edu/etd\%5Cnhttp://scholarscompass.vcu.edu/etd

Barnett, A. G., Graves, N. C., \& Blakely, T. (2015). What is the impact of research funding on research productivity?

Barnett, A. H., Ault, R. W., \& Kaserman, D. L. (1988). The Rising Incidence of Coauthorship in Economics: Further Evidence. The Review of Economics and Statistics, 70(3), 539. https://doi.org/10.2307/1926798

Baumann, A. A., Carothers, B. J., Landsverk, J., Kryzer, E., Aarons, G. A., Brownson, R. C., ... Proctor, E. K. (2019). Evaluation of the Implementation Research Institute: Trainees' Publications and Grant Productivity. Administration and Policy in Mental Health and Mental Health Services Research, 47(2), 254-264. https://doi.org/10.1007/s10488-019-00977-4

Beaver, D. D. B. (2001). Reflections on scientific collaboration (and its study): Past, present, and future. Scientometrics, 52(3), 365-377. https://doi.org/10.1023/A:1014254214337

Butler, L. (2004). What Happens When Funding is Linked to Publication Counts? In Handbook of Quantitative Science and Technology Research (pp. 389-405). https://doi.org/10.1007/1-4020-2755-9_18

Callaghan, C. W. (2015). Crowdsourced "R\&D" and medical research. British Medical Bulletin, 115(1), 67-76. https://doi.org/10.1093/bmb/ldv035

Chin, W. W. (2010). How to write up and report PLS analyses. Handbook of Partial Least Squares: Concepts, Methods and Applications, VE Vinzi, WW Chin, J. Henseler, and $H$. Wang. New York: Springer.

Defazio, D., Lockett, A., \& Wright, M. (2009). Funding incentives, collaborative dynamics and scientific productivity: Evidence from the EU framework program. Research Policy, 38(2), 293-305. https://doi.org/10.1016/j.respol.2008.11.008

Dhillon, S. K., Ibrahim, R., Selamat, A., \& Sani, S. I. (2013). Diagnosis of Key Performance Indicators Delivery Process Using Viable System Model. International Journal of Digital Content Technology and Its Applications(JDCTA), 7(13).

Ductor, L. (2015). Does co-authorship lead to higher academic productivity? Oxford Bulletin of Economics and Statistics, 77(3), 385-407. https://doi.org/10.1111/obes.12070

Feng, G. C. (2020). Research Performance Evaluation in China: A Big Data Analysis. SAGE Open, 10(1). https://doi.org/10.1177/2158244019901257

Fornell, C., \& Larcker, D. F. (1981). Evaluating Structural Equation Models with Unobservable Variables and Measurement Error. Journal of Chemical Information and Modeling. https://doi.org/10.1017/CBO9781107415324.004

Fuzi, I. F., \& Fuzi, M. A. Y. (2019). The Influence of Human Resource Practices on Job Satisfaction: Empirical Investigation of Jordan Hotels. International Business Education Journal, 12(1), 15-24. https://doi.org/10.5296/ijhrs.v8i4.13644

Garcia, C. E., \& Sanz-Menéndez, L. (2005). Competition for funding as an indicator of research competitiveness. Scientometrics, 64(3), 271-300. https://doi.org/10.1007/s11192-005-0251-x 
faiz Abozaid, R., Mansoor, R. M., Shah, S. S. H., Harjan, S. A., Alalimi, A., \& Mustafa, A. (2019). Perceived overqualification and its positive impact on organization employee's behavior. International Journal of Research in Business and Social Science (2147-4478), 8(6), 58-71.

Ghabban, F., Selamat, A., Ibrahim, R., Krejcar, O., Maresova, P., \& Herrera-Viedma, E. (2019). The influence of personal and organizational factors on researchers' attitudes towards sustainable research productivity in Saudi universities. Sustainability (Switzerland), 11(17). https://doi.org/10.3390/su11174804

Ghran, L. A. Z., Jameel, A. S., \& Ahmad, A. R. (2019). The effect of organizational justice on job satisfaction among secondary school teachers. International Review, 3(4), 8493.

Hair, J. F., Sarstedt, M., Hopkins, L., \& Kuppelwieser, V. G. (2014). Partial least squares structural equation modeling with R. Practical Assessment, Research and Evaluation, 21(1), 1-16. https://doi.org/10.1108/ebr-10-2013-0128

Hair Jr, J. F., Hult, G. T. M., Ringle, C., \& Sarstedt, M. (2016). A primer on partial least squares structural equation modeling (PLS-SEM). Sage publications.

Hassan, H., Mohamad, R., Haslinda, R., \& Mohd, R. (2020). Factors Affecting Students ' Academic Performance in Higher Education: Evidence from Accountancy Degree Programme. International Business Education Journal, 13(1), 1-16.

He, Z. L., Geng, X. S., \& Campbell-Hunt, C. (2009). Research collaboration and research output: A longitudinal study of 65 biomedical scientists in a New Zealand university. Research Policy, 38(2), 306-317. https://doi.org/10.1016/j.respol.2008.11.011

Henseler, J., Ringle, C. M., \& Sinkovics, R. R. (2009). The use of partial least squares path modeling in international marketing. Advances in International Marketing, 20(May 2014), 277-319. https://doi.org/10.1108/S1474-7979(2009)0000020014

Hottenrott, H., \& Lawson, C. (2017). Fishing for complementarities: Research grants and research productivity. International Journal of Industrial Organization, 51, 1-38. https://doi.org/10.1016/j.ijindorg.2016.12.004

Ibegbulam, I. J., \& Jacintha, E. U. (2016). Factors That Contribute to Research and Publication Output Among Librarians in Nigerian University Libraries. Journal of Academic Librarianship, 42(1), 15-20. https://doi.org/10.1016/j.acalib.2015.09.007

Iqbal, M. Z., \& Mahmood, A. (2011). Factors related to low research productivity at higher education level. Asian Social Science, 7(2), 188-191. https://doi.org/10.5539/ass.v7n2p188

Jameel, A. S., \& Ahmad, A. R. (2019a). Leadership and Performance of Academic Staff in Developing Countries. The 33rd International Business Information Management Association Conference, 6101-6106. Granada, Spain: IBIMA.

Jameel, A. S., \& Ahmad, A. R. (2019b). The effect of Transformational Leadership on Job Satisfaction among Academic Staff. In The 34th International Business Information Management Association (IBIMA) Conference: 13-14 November 2019, Madrid, Spain. 
Jameel, A. S, \& Ahmad, A. R. (2020). The Mediating Role of Job Satisfaction between Leadership Style and Performance of Academic Staff. International Journal of Psychosocial Rehabilitation, 24(04), 2399-2414. https://doi.org/10.37200/IJPR/V24I4/PR201349

Jameel, A. S, Mahmood, Y. N., \& Jwmaa, S. J. (2020). Organizational Justice and Organizational Commitment among Secondary School teachers. Cihan UniversityErbil Journal of Humanities and Social Sciences, 4(1), 1-6. https://doi.org/10.24086/cuejhss.vol4n1y2020.pp1-7

Jameel, A. S. (2018). Challenges facing students toward ICT library adoption. International Conference on Accounting, Business, Economics and Politics, (April), 231-237. https://doi.org/10.23918/icabep2018p23

Jameel, A. S., \& Ahmad, M. A. (2018). Determine some factors that affect to adoption of ecommerce among small and medium enterprises in Erbil. Polytechnic Journal, 8(1). https://doi.org/10.25156/ptj.2018.8.1.146

Jameel, A. S., Karem, M. A., \& Mahmod, N. Z. (2017). A Review of the Impact of ICT on Business Firms. International Journal of Latest Engineering and Management Research, 2(1), 15-19. https://doi.org/10.2139/ssrn.2906774

Karem, M. A., Mahmood, Y. N., Jameel, A. S., \& Ahmad, A. R. (2019). The Effect of Job Satisfaction and Organizational Commitment on Nurses' Performance. Humanities and Social Sciences Reviews, 7(6), 332-339. https://doi.org/10.18510/hssr.2019.7658

Kato, M., \& Ando, A. (2013). The relationship between research performance and international collaboration in chemistry. Scientometrics, 97(3), 535-553. https://doi.org/10.1007/s11192-013-1011-y

Khademi, T., Ismail, K., Lee, C. T., \& Shafaghat, A. (2015). Enhancing commercialization level of academic research outputs in research university. Jurnal Teknologi, 74(4), 141-151. https://doi.org/10.11113/jt.v74.4622

Khan, M. R., \& Ghouri, A. M. (2018). Enhancing Customer Satisfaction and Loyalty through Customer-Defined Market Orientation and Customer Inspiration: A Critical Literature Review. International Business Education Journal, 11(1), 25-39.

Liu, N. C., \& Cheng, Y. (2005). The academic ranking of world universities. Higher Education in Europe, 30(2), 127-136. https://doi.org/10.1080/03797720500260116

Locke, E. A. (1976). The nature and causes of job satisfaction. In Handbook of Industrial and Organizational Psychology.

Mahmood, Y. N., Raewf, M. B., \& Hamadany, Z. S. A.-. (2019). A Study on the Perceptual Relationship between Overtime and Output: Case Study of Knowledge. Cihan University-Erbil Journal of Humanities and Social Sciences, 3(1), 27-31. https://doi.org/10.24086/cuejhss.vol3n1y2019.pp27-31

Mcneece, C. A. (1981). Linked references are available on JSTOR for this article : Faculty Publications, Tenure, And Job Satisfaction In Graduate Social Work Programs. Journal of Education for Social Work, 17(3), 13-19.

Milesi, C., Brown, K. L., Hawkley, L., Dropkin, E., \& Schneider, B. L. (2014). Charting the 
Impact of Federal Spending for Education Research: A Bibliometric Approach. Educational Researcher, 43(7), 361-370. https://doi.org/10.3102/0013189X14554002

Mousa, T. S., Jameel, A. S., \& Ahmad, A. R. (2019). The Impact of Attitude, Subjective Norm and Information Communications Technology on Knowledge Sharing among Academic Staff. International Journal of Psychosocial Rehabilitation, 23(02), 704717.

Nafukho, F. M., Wekullo, C. S., \& Muyia, M. H. (2019). Examining research productivity of faculty in selected leading public universities in Kenya. International Journal of Educational Development, https://doi.org/10.1016/j.ijedudev.2019.01.005

66(February), 44-51.

Newman, M. E. J. (2011). The structure of scientific collaboration networks. The Structure and Dynamics of Networks, 9781400841, 221-226. https://doi.org/10.1515/9781400841356.221

Olakunle, S. A., \& Olanrewaju, P. S. (2019). Relationship Between Information Literacy Skills and Research Productivity of Researchers in Nigeria, and the Mediating Role of Socio-Economic Factors. LIBRES: Library \& Information Science Research Electronic Journal, 29(1).

Personal, M., \& Archive, R. (2008). Munich Personal RePEc Archive The influence of stress and satisfaction on productivity. Munich Personal RePEC Archive, 1-26.

Pezzoni, M., Sterzi, V., \& Lissoni, F. (2012). Career progress in centralized academic systems: Social capital and institutions in France and Italy. Research Policy, 41(4), 704-719. https://doi.org/10.1016/j.respol.2011.12.009

Porter, L. W., \& Lawler, E. E. (1968). Managerial Attitudes and Performance. In Homewood, IL: Irwin. https://doi.org/10.2307/2521994

Pouris, A., \& Pouris, A. (2010). Competing in a globalising world: International ranking of South African universities. Procedia - Social and Behavioral Sciences, 2(2), 515-520. https://doi.org/10.1016/j.sbspro.2010.03.055

Raewf, M. B., \& Thabit, T. H. (2015). The Student' s Satisfaction Influential Factors at Cihan University. International Journal Of Advanced Research in Engineering \& Management (IJAREM) |, 01(02), 63-72. Retrieved from http://ssrn.com/abstract $=2638744$

Rubin, A., \& Callaghan, C. W. (2019). Entrepreneurial orientation, technological propensity and academic research productivity. Heliyon, 5(8), e02328. https://doi.org/10.1016/j.heliyon.2019.e02328

Shahbazi-Moghadam, M., Salehi, H., Ale Ebrahim, N., Mohammadjafari, M., \& Gholizadeh, H. (2015). Effective factors for increasing university publication and citation rate. Asian Social Science, 11(16), 338-348. https://doi.org/10.5539/ass.v11n16p338

Shin, J. C., \& Jung, J. (2014). Academics job satisfaction and job stress across countries in the changing academic environments. Higher Education, 67, 603-620. https://doi.org/10.1007/s10734-013-9668-y

Shrum, W. (2005). Reagency of the Internet, or, how I became a guest for science. Social 
Studies of Science, 35(5), 723-754. https://doi.org/10.1177/0306312705052106

SJR. (2020). Scimago Journal and Country Rank. Retrieved from Scimago Journal and Country Rank website: https://www.scimagojr.com/countryrank.php?region=Middle East

Teodorescu, D. (2000). Correlates of faculty publication productivity: A cross-national analysis. Higher Education, 39, 201-222.

Thabit, T. H., \& Raewf, M. B. (2015). The Impact of Voluntary Disclosure on SMEs in Developing Countries. 6th International Conference on Global Social Entrepreneurship (Kota Bharu) 2016, 46.

Thabit, T. H., \& Raewf, M. B. (2018). The Evaluation of Marketing Mix Elements: A Case Study. International Journal of Social Sciences \& Educational Studies, 4(4), 100109. https://doi.org/10.23918/ijsses.v4i4p100

Toutkoushian, R. K., Porter, S. R., Danielson, C., \& Hollis, P. R. (2003). Using Publications Counts to Measure an Institution' $\mathrm{s}$ Research Productivity. Research in Higher Education, 44(2), 121-148.

United States Institute of Peace (2008), Special Report, Higher Education and the Future of Iraq. https://www.files.ethz.ch/isn/46082/sr195.pdf

Wilkinson, B. R., \& Durden, C. H. (2015). Inducing structural change in academic accounting research. Critical Perspectives on Accounting, 26, 23-36. https://doi.org/10.1016/j.cpa.2014.03.002

Yazit, N., \& Zainab, A. N. (2007). Publication productivity of Malaysian authors and institutions in LIS. Malaysian Journal of Library and Information Science, 12(2), 3555.

Ynalvez, M. A., \& Shrum, W. M. (2011). Professional networks, scientific collaboration, and publication productivity in resource-constrained research institutions in a developing country. Research Policy, 40(2), 204-216. https://doi.org/10.1016/j.respol.2010.10.004 